\title{
High Resolution Maps of Climatological Parameters for Analyzing the Impacts of Climatic Changes on Swiss Forests
}

\author{
Andreas Paul Zischg ${ }^{1, *} \mathbb{0}$, Päivi Gubelmann ${ }^{2}$, Monika Frehner ${ }^{3,4}$ and Barbara Huber ${ }^{2}$ \\ 1 Institute of Geography, Oeschger Centre for Climate Change Research, University of Bern, \\ 3012 Bern, Switzerland \\ 2 Abenis AG, 7000 Chur, Switzerland \\ 3 Forest Engineering Frehner, 7320 Sargans, Switzerland \\ 4 Department of Environmental Systems Science, Institute of Terrestrial Ecosystems, \\ Swiss Federal Institute of Technology Zurich, 8092 Zurich, Switzerland \\ * Correspondence: andreas.zischg@giub.unibe.ch; Tel.: +41-31-631-88-39
}

Received: 17 June 2019; Accepted: 22 July 2019; Published: 25 July 2019

\begin{abstract}
Assessing the impacts of climatic changes on forests requires the analysis of actual climatology within the forested area. In mountainous areas, climatological indices vary markedly with the micro-relief, i.e., with altitude, slope, and aspect. Consequently, when modelling potential shifts of altitudinal belts in mountainous areas due to climatic changes, maps with a high spatial resolution of the underlying climatological indices are fundamental. Here we present a set of maps of climatological indices with a spatial resolution of 25 by $25 \mathrm{~m}$. The presented dataset consists of maps of the following parameters: average daily temperature high and low in January, April, July, and October as well as of the year; seasonal and annual thermal continentality; first and last freezing day; frost-free vegetation period; relative air humidity; solar radiation; and foehn conditions. The parameters represented in the maps have been selected in a knowledge engineering approach. The maps show the climatology of the periods 1961-1990 and 1981-2010. The data can be used for statistical analyses of forest climatology, for developing tree distribution models, and for assessing the impacts of climatic changes on Swiss forests.
\end{abstract}

Keywords: forest climatology; Switzerland; temperature; relative air humidity; thermal continentality; foehn winds; expert elicitation; knowledge engineering

\section{Introduction}

Forests in mountainous areas are providing important ecosystem services [1]. Most importantly, mountain forests protect settlements, roads and other infrastructure from natural hazards [2]. This protection function may be altered by the effects of climatic changes, invasive species, disturbances, or unsustainable forest management practices [3-6]. Moreover, forest disturbances can lead to an increase in flood hazards by large wood in rivers [7]. Hence, assessing the long-term sustainability and stability of mountain forests is a key requirement for assessing natural hazard risks in the Alps [8,9]. Forest managers today need to adapt to the effects of climatic changes. This requires accurate, reliable and localized information about potential future dynamics of forests [10]. As empirical knowledge on localized effects of climatic changes is yet rare, the assessment of future dynamics is merely been done with the help of simulation models (e.g., References [11-14]). However, as the vulnerability of forests to climate changes is not always known, these approaches require local expertise and expert knowledge to be integrated into the procedures for climate impact assessment [15]. Thus, for confronting these 
challenges and for closing the science-practice gap in forest management $[16,17]$, transdisciplinary approaches or even post-normal science approaches [18] are needed.

The Federal Office for the Environment in Switzerland is aiming at developing an expert system for supporting forest managers in their decisions regarding the adaptation of their forests to the effects of climatic changes in the long-term. As a first and basic step to achieve this goal, a fundamental dataset of climatological indices had to be elaborated. These data aim at providing fundamental geodata for statistical analyses of the spatial distribution of the different forest typologies and their altitudinal belts, for developing tree distribution models, and for assessing the impacts of climatic changes on Swiss forests. The parameters of forest climatology that are represented in maps have been selected by a combination of a literature review [19] and an expert elicitation or knowledge engineering approach [20-23]. In an iterative process, we screened first the literature for environmental parameters that influence the spatial and altitudinal distribution of tree species and forest typologies. In a second step, we discussed this selection of parameters with local experts. Consequently, we added further parameters or deleted parameters from the list not being assessed as regionally relevant.

The final set of maps show these climatological indices: average daily temperature high and low in January, April, July, and October as well as of the year; seasonal and annual thermal continentality; first and last freezing day; frost-free vegetation period; relative air humidity; solar radiation; and foehn conditions. In the following, we present the data and methods used to elaborate these maps. The overall dataset was made available in the data repository ZENODO [24]

\section{Maps of Climatological Forest Parameters}

All of the elaborated maps have a spatial resolution of 25 by $25 \mathrm{~m}$. The map extent is aligned to the digital elevation model DHM25 of the Federal Office of Topography swisstopo [25]. The raster data are georeferenced in the Swiss coordinate system CH1903/LV03 (EPSG 21781) and archived in an ASCII-grid format.

\subsection{Air Temperature}

Air temperature is one of the most important climate parameters for the altitudinal belts of forest typologies. In addition, daily temperature fluctuations are important for forest climatology. In continental, inner-alpine areas at the same altitude, the average daily temperature fluctuations are remarkably greater than on the northern edge of the Alps or even on an isolated summit in the Jura mountains or in the Prealps. In analyzing temperature fluctuations for forest climatology purposes one has to distinguish between the temperature range (i.e., the difference between the mean value of all daily temperature maxima and the mean value of all daily temperature minima of a considered period) and the daily temperature variation (i.e., the difference between the mean high and low of the averaged daily course of temperature of a considered period). The reason is that both the temperature maximum and the temperature minimum can occur at any time of day. The mean daily variation of air temperature is the difference between the mean daily temperature high, which usually occurs at a station at 2:00 p.m., and the mean daily temperature low, which usually occurs at sunrise. To determine the mean high and low, the mean annual daily cycle between 1961 and 1990 is to be calculated from 0:00 a.m. to 11:50 p.m. The temperature curve of a certain period (e.g., month) can then be determined as a function of the time of day. This average temperature curve is similar to a sinusoidal curve. The highest value of this temperature curve is now referred to as the mean daily high of the temperature, the lowest value of this curve correspondingly as the mean daily low of the temperature. Therefore, the mean daily maximum temperature must be higher or at least equal to the mean daily temperature high, and the mean daily minimum temperature must always be lower or equal to the mean daily temperature low. The mean daily temperature low is occurring around 7.00 a.m.; the mean daily high is occurring at around 2:00 p.m. The difference between the mean daily high and the mean daily low, i.e., the mean daily variation of the air temperature at a certain location, is a measure of the thermal continentality of a location because it represents the mean radiation-related 
temperature change of a location. In contrast, the mean daily temperature range is always greater than the mean (radiation-related) daily variation. The difference between the mean daily range and the mean daily variation describes the aperiodic component. The aperiodic component is a measure of the frequency with which air masses with different temperatures are replaced. The reason why the mean daily variation was taken into account is that the effect of the lowest value is quite different when it occurs at night than when it occurs during the day. If frost occurs during the night, it is much more harmful to the plant, as in many cases it is accompanied by radiation which causes even lower minima on the surface of the plant. During the day, on the other hand, an air temperature that falls below $0{ }^{\circ} \mathrm{C}$ due to a brief cold advection hardly has a negative effect on the plant surface, as the radiation from the plant surface causes significantly higher temperatures. Conversely, a brief nocturnal foehn event at night, which drives the temperature to high values, has hardly any effect on a forest tree, since the tree is photosynthetically inactive at night. If, on the other hand, a maximum temperature value is coupled with high irradiation, this has a great influence on the plants.

In Switzerland, there are several places with a high daily variation of temperature. These are inner-Alpine valleys in the Valais, in Graubünden or in northern Ticino, where average daily variations of $10^{\circ} \mathrm{C}$ and more are possible. Conversely, these areas are relatively unaffected by air mass changes, so that the aperiodic component there is relatively small at 1.5 to $2{ }^{\circ} \mathrm{C}$. On the other hand, exposed peaks in the Pre-Alps show only a very low daily temperature variation, which barely exceeds $2{ }^{\circ} \mathrm{C}$. However, the aperiodic component can reach up to $3^{\circ} \mathrm{C}$ in these layers, because air mass changes take place very frequently in such layers. Generally, it can be said that the mean daily temperature cycle throughout Switzerland with a range from 2 to over $10^{\circ} \mathrm{C}$ shows clearly greater regional differences than the aperiodic component, which only fluctuates between about 2 and $4{ }^{\circ} \mathrm{C}$.

The mean temperature was derived by averaging the temperature lows and highs of the periods. In addition, we elaborated a map of the mean temperature during the vegetation period (April-September).

\subsubsection{Interpolation}

Since temperatures in Switzerland have only been measured every 10 min since the 1980s, the daily variations and aperiodic components could only be determined in the period 1981-2010. In order to obtain daily variations for the desired time period 1961-1990, we calculated the mean minimum and mean maximum at all stations for this time period and corrected them for the aperiodic components of the years 1981-2010. With this method, the mean daily low and the mean daily high could be determined at all stations of MeteoSwiss. This method was applied to the entire year as well as to the months of January, April, July and October, which are representative for the four seasons. The basis for the now calculated maps were thus the mean daily lows and the mean daily highs of the period 1961-1990 in the whole year, as well as in the months January, April, July and October. Since the absolute maximum and minimum temperatures can be significant for the flora, maps of the absolute temperature minima (1864 to 1990) and the absolute temperature maxima (1864 to 1990) were also produced.

The interpolation of the measured values to the entire space in the targeted high spatial resolution bases on a gradient approach. First, we elaborated temperature maps at a selected altitude. Second, these temperature maps at the different altitudes were overlaid. Finally, the gradients between neighboring temperature layers were used to interpolate and project temperatures on topography by using the digital terrain model.

For this, we calculated the values of the stations at altitudes of 500, 1000, 1500, 2000 and $3500 \mathrm{~m}$ with the aid of seasonal gradients derived by neighboring station data. These projected values were interpolated over the entire area at the altitudes mentioned. The temperature maps at an altitude of $3500 \mathrm{~m}$ were prepared in order to model the gradients between $2000 \mathrm{~m}$ and $3500 \mathrm{~m}$ over an area. The values at an altitude of $3500 \mathrm{~m}$ a.s.l. were based on the measured value of the Jungfraujoch station only. We used a slight horizontal gradient from north to south $\left(+1^{\circ} \mathrm{C}\right.$ in the south at Chiasso and $-1^{\circ} \mathrm{C}$ 
in the north at Schaffhausen) to correct for the overall north-south temperature gradient as suggested by Reference [26].

\subsubsection{Local Temperature Corrections}

In a further step, we corrected the resulting maps with selected microclimatological biases, i.e., we slightly corrected the interpolated temperatures at remarkably sunny and shadowy hillslopes, and we added temperature inversion effects of cold air layers in topographic depressions. In a mountainous country like Switzerland with its high variability in topography, considerable temperature differences often occur within short distances. This is particularly the case when a strong temperature inversion close to the ground can form in an area during clear nights due to radiation.

The temperature on northern slopes was lowered during the day but increased on southern slopes as suggested by [27]. These corrections were made for the maps of January, October, and the year. In April and July, the exposure differences are negligibly small due to the strong valley winds and the unstable air stratification. To apply these corrections, we computed the solar radiation. The temperature at maximally shadowed slopes was corrected by $-1{ }^{\circ} \mathrm{C}$ and at maximally sunny slopes by $+1^{\circ} \mathrm{C}$. Temperature corrections between these extremes have been interpolated linearly and usually reached small amounts of less than $+/-0.5^{\circ} \mathrm{C}$, since in most cases the stations are located in only slightly inclined positions.

More important were the corrections at stations with cold air layers in deeper valleys and topographic depressions. Here, the temperature lows could reach up to $-10{ }^{\circ} \mathrm{C}$ at individual stations, for example in January at the Samedan station in the Upper Engadine, which lies in an extremely cold air layer. Especially in closed valley basins of the Alps and the Jura, such inversions often form, which are also called cold air lakes. Cold air layers are of great importance for the flora, as frost occurs in cold air layers much later in spring than on a slope at the same altitude. It can happen that tree species such as beech or, to a lesser extent, fir, which are sensitive to late frost or extremely low winter temperatures, no longer thrive in areas with strong cold air layers. Therefore, it is important to map the cold air layers in topographic depressions as accurately as possible, at least those that influence entire valleys. For some areas, such as Goms, Upper Engadine or La Brévine in the Neuchâtel Jura, the strength of the cold air layers could be estimated well, as there are measuring stations at the bottom of the valley. In other places, the strength of the cold air layers had to be estimated on the basis of extensive thermal surveys and data from older climate stations. With these methods, it was possible to determine the temperature deviation from the free atmosphere in the deepest part of the valley bottom. In a second step, the thickness of a cold air layer had to be determined. It was generally assumed that no cold air layer existed above a damming obstacle, e.g., a valley bar or a valley narrowing. In most cases, these obstacles are not more than $150 \mathrm{~m}$ thick. However, there are areas with a height of the damming obstacle of up to $600 \mathrm{~m}$. In topographical depressions without a drain, such as those found in the Jura mountains, the procedure was basically the same as in a valley. Here, too, the lowest air temperature was assumed for the lowest point of the basin. It was also assumed that no cold air layer existed above the deepest surrounding edge of the basin. For each cold air layer, the height of the temperature inversion layer and the height of the valley bottom above sea level is derived. Moreover, a temperature at the bottom of each cold air layer was assumed on the basis of neighboring temperature measurements. The temperature of the original maps was corrected in the mapped cold air layers by means of the altitudinal temperature gradients. Example maps are shown in Figure 1. The resulting maps are listed and described in Table 1. 


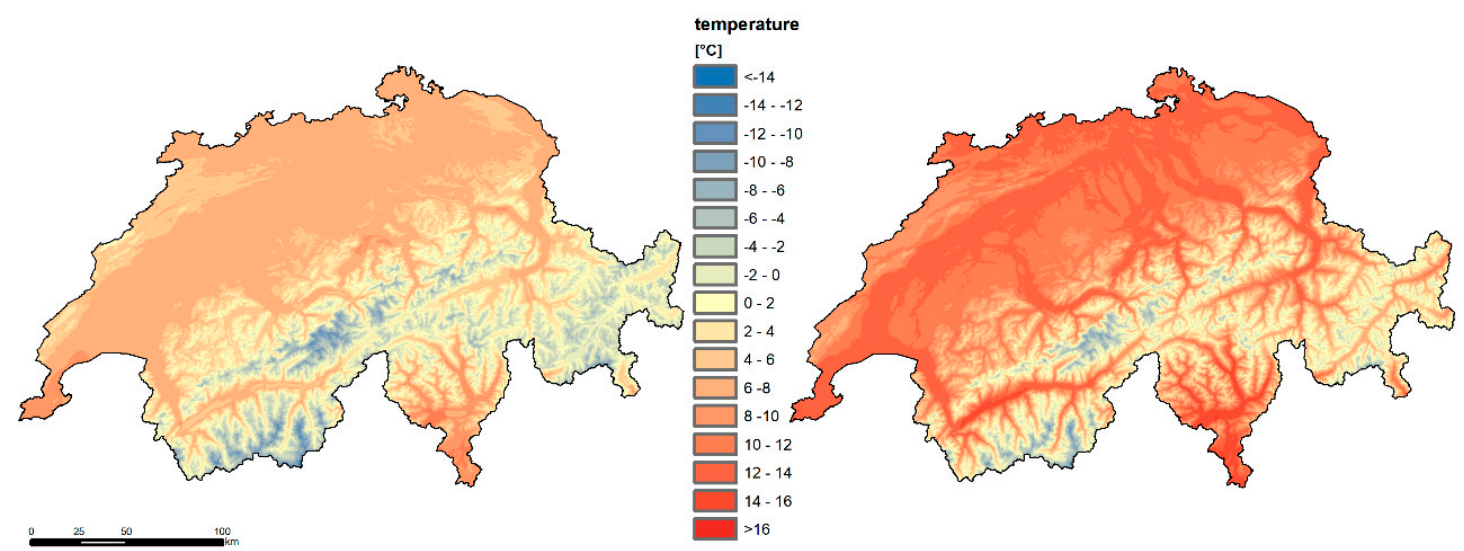

Figure 1. Mean daily temperature low (left) and (high) during the year in the period 1981-2010.

Table 1. Resulting temperature maps and intermediary files.

\begin{tabular}{|c|c|c|c|}
\hline Map Abbreviation & Parameter & Unit & Period \\
\hline TJANMIN6190 & mean temperature low in January & ${ }^{\circ} \mathrm{C}$ & 1961-1990 \\
\hline TJANMAX6190 & mean temperature high in January & ${ }^{\circ} \mathrm{C}$ & 1961-1990 \\
\hline TJANMEAN6190 & mean temperature in January & ${ }^{\circ} \mathrm{C}$ & 1961-1990 \\
\hline TAPRMIN6190 & mean temperature low in April & ${ }^{\circ} \mathrm{C}$ & 1961-1990 \\
\hline TAPRMAX6190 & mean temperature high in April & ${ }^{\circ} \mathrm{C}$ & 1961-1990 \\
\hline TAPRMEAN6190 & mean temperature in April & ${ }^{\circ} \mathrm{C}$ & 1961-1990 \\
\hline TJULMIN6190 & mean temperature low in July & ${ }^{\circ} \mathrm{C}$ & 1961-1990 \\
\hline TJULMAX6190 & mean temperature high in July & ${ }^{\circ} \mathrm{C}$ & 1961-1990 \\
\hline TJULMEAN6190 & mean temperature in July & ${ }^{\circ} \mathrm{C}$ & 1961-1990 \\
\hline TOCTMIN6190 & mean temperature low in October & ${ }^{\circ} \mathrm{C}$ & 1961-1990 \\
\hline TOCTMAХ6190 & mean temperature high in October & ${ }^{\circ} \mathrm{C}$ & 1961-1990 \\
\hline TOCTMEAN6190 & mean temperature in October & ${ }^{\circ} \mathrm{C}$ & $1961-1990$ \\
\hline TYYMIN6190 & mean temperature low in the year & ${ }^{\circ} \mathrm{C}$ & 1961-1990 \\
\hline TYYMAX6190 & mean temperature high in the year & ${ }^{\circ} \mathrm{C}$ & 1961-1990 \\
\hline TYYMEAN6190 & mean temperature in the year & ${ }^{\circ} \mathrm{C}$ & 1961-1990 \\
\hline TAMJJASMEAN6190 & mean temperature April-September & ${ }^{\circ} \mathrm{C}$ & 1961-1990 \\
\hline TABSMIN & absolute minimum temperature of the period & ${ }^{\circ} \mathrm{C}$ & 1894-1990 \\
\hline TABSMAX & absolute maximum temperature of the period & ${ }^{\circ} \mathrm{C}$ & 1894-1990 \\
\hline TJANMIN9110 & mean temperature low in January & ${ }^{\circ} \mathrm{C}$ & $1981-2010$ \\
\hline TJANMAX8110 & mean temperature high in January & ${ }^{\circ} \mathrm{C}$ & 1981-2010 \\
\hline TJANMEAN8110 & mean temperature in January & ${ }^{\circ} \mathrm{C}$ & $1981-2010$ \\
\hline TAPRMIN8110 & mean temperature low in April & ${ }^{\circ} \mathrm{C}$ & 1981-2010 \\
\hline TAPRMAX8110 & mean temperature high in April & ${ }^{\circ} \mathrm{C}$ & 1981-2010 \\
\hline TAPRMEAN8110 & mean temperature in April & ${ }^{\circ} \mathrm{C}$ & $1981-2010$ \\
\hline TJULMIN8110 & mean temperature low in July & ${ }^{\circ} \mathrm{C}$ & $1981-2010$ \\
\hline TJULMAX8110 & mean temperature high in July & ${ }^{\circ} \mathrm{C}$ & $1981-2010$ \\
\hline TJULMEAN9110 & mean temperature in July & ${ }^{\circ} \mathrm{C}$ & 1981-2010 \\
\hline TOCTMIN8110 & mean temperature low in October & ${ }^{\circ} \mathrm{C}$ & $1981-2010$ \\
\hline TOCTMAХ9110 & mean temperature high in October & ${ }^{\circ} \mathrm{C}$ & 1981-2010 \\
\hline TOCTMEAN8110 & mean temperature in October & ${ }^{\circ} \mathrm{C}$ & 1981-2010 \\
\hline TYYMIN8110 & mean temperature low in the year & ${ }^{\circ} \mathrm{C}$ & 1981-2010 \\
\hline TYYMAX8110 & mean temperature high in the year & ${ }^{\circ} \mathrm{C}$ & 1981-2010 \\
\hline TYYMEAN8110 & mean temperature in the year & ${ }^{\circ} \mathrm{C}$ & 1981-2010 \\
\hline COLDAIRLAYER & $\begin{array}{l}\text { temperature difference between the upper and } \\
\text { lower boundary of the cold air layer, the altitude of } \\
\text { the lower and upper boundary of the cold air layer }\end{array}$ & $\begin{array}{c}{ }^{\circ} \mathrm{C} \\
\text { m a.s.l. }\end{array}$ & 1981-2010 \\
\hline
\end{tabular}

\subsection{Daily Temperature Variation}

The temperature maps provided the basis for the elaboration of maps showing the daily temperature variation. These temperature continentality maps result from the difference between the 
temperature low and the temperature high of the respective time period (month or year). The resulting maps are listed and described in Table 2.

Table 2. Resulting temperature continentality maps and intermediary files.

\begin{tabular}{cccc}
\hline Map Abbreviation & Parameter & Unit & Period \\
\hline CONTJAN & mean daily temperature variation in January & ${ }^{\circ} \mathrm{C}$ & $1981-2010$ \\
CONTAPR & mean daily temperature variation in April & ${ }^{\circ} \mathrm{C}$ & $1981-2010$ \\
CONTJUL & mean daily temperature variation in July & ${ }^{\circ} \mathrm{C}$ & $1981-2010$ \\
CONTOCT & mean daily temperature variation in October & ${ }^{\circ} \mathrm{C}$ & $1981-2010$ \\
CONTYY & mean daily temperature variation in the year & ${ }^{\circ} \mathrm{C}$ & $1981-2010$ \\
CONTABS & absolute daily temperature variation in the period & ${ }^{\circ} \mathrm{C}$ & $1894-1990$ \\
\hline
\end{tabular}

\subsection{Average First and Last Freezing Day of the Year}

The last frost day in spring is decisive for the occurrence of many tree species (frost tolerance and phenology). The first frost in autumn has less of an influence, as it limits the growth period of the trees. The maps showing the average first and average last frost day of the year were both calculated with the same procedure. The maps are based on measurement data for the period 1961-1990. A day was defined as a "frost day" if the minimum temperature of that day is below $0{ }^{\circ} \mathrm{C}$. In a first step, we calculated the mean last frost day of the year for the period 1961-1990 for each meteorological station. Each station thus received a value between 1 and 365 ( $1=1$ January). Based on this analysis, maps of the last frost have been elaborated for the heights of $500 \mathrm{~m}, 1000 \mathrm{~m}, 1500 \mathrm{~m}$ and $2000 \mathrm{~m}$ a.sl. For the calculation of the mean last frost day on the real heights of the digital terrain model with a target resolution of $25 \mathrm{~m}$, the gradients from the frost maps on 500, 1000, 1500 and $2000 \mathrm{~m}$ a.sl. on each grid point were calculated between the different height levels. Below $500 \mathrm{~m}$ a.s.l. the gradient between 500 and $1000 \mathrm{~m}$ a.s.l. was used, above $2000 \mathrm{~m}$ a.s.l. the gradient between 1500 and $2000 \mathrm{~m}$ was used. The map for the mean first frost day was calculated according to a similar procedure. Both maps were subsequently corrected for cold air layers. For each cold air layer, the correction (in days) for the lowest point of the lake was determined. The correction value decreases linearly towards the upper boundary of the cold air layer reaching zero at the upper boundary. Finally, fixed limits were set for the occurrence of the last and first frost day. For the average last frost day, this is day 196 (July 15). For the average first frost day, this is day 225 (August 13). From these maps, the duration of frost-free vegetation period has deviated. The duration of the frost-free vegetation period is particularly decisive for frost-sensitive tree species such as beech and fir. The resulting maps are listed and described in Table 3 .

Table 3. Resulting map of first and last freezing day of the year.

\begin{tabular}{cccc}
\hline Map Abbreviation & Parameter & Unit & Period \\
\hline LFD & average last frost day in a year & no. of day & $1981-2010$ \\
FFD & average first frost day in a year & no. of day & $1981-2010$ \\
VEGPER & durations of frost-free vegetation period & days & $1981-2010$ \\
\hline
\end{tabular}

\subsection{Relative Air Humidity}

Air humidity is particularly important for vegetation during the day because the plant is photosynthetically active and at low air humidity either evaporates a lot or has to close its stomata, which prevents it from assimilating carbon. Air humidity during the night, in contrast, is of much less important, as the plant hardly evaporates during the night as a result of the stoma closure.

In accordance with the procedure for the production of temperature maps with altitude gradients and area interpolation, we elaborated maps of the monthly average relative air humidity at 1:30 p.m. for the months of January, April, July, and October as well as for the annual average in the period 1981-2010. In a second step, we elaborated maps of the monthly and annual average relative air 
humidity at 6:00 a.m. for the months of January, April, July and October for calculating the mean in the period 1981-2010. Figure 2 shows the average annual relative air humidity at 1:30 p.m. in Switzerland. The resulting maps are listed and described in Table 4.
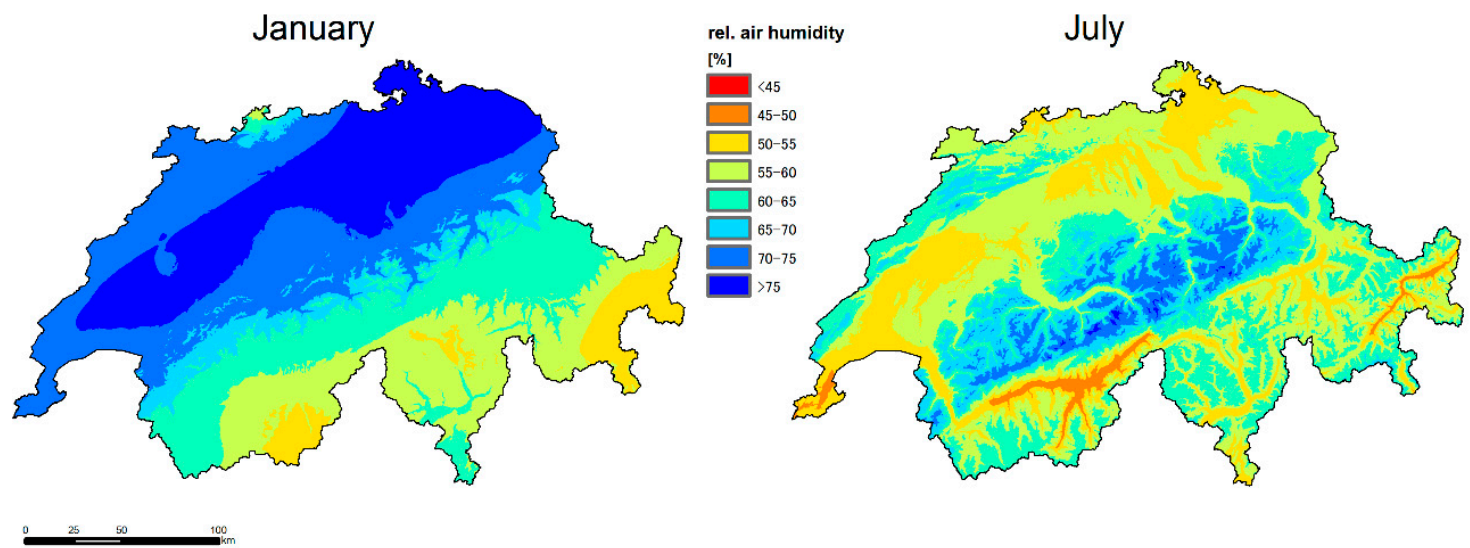

Figure 2. Mean daily relative air humidity at 1:30 p.m. in January (left) and July (high) in the period 1981-2010.

Table 4. Resulting maps of relative air humidity.

\begin{tabular}{cccc}
\hline Map Abbreviation & Parameter & Unit & Period \\
\hline MLFJAN8110 & mean daily relative air humidity in January & $\%$ & $1981-2010$ \\
MLFAPR8110 & mean daily relative air humidity in April & $\%$ & $1981-2010$ \\
MLFJUL8110 & mean daily relative air humidity in July & $\%$ & $1981-2010$ \\
MLFOCT8110 & mean daily relative air humidity in October & $\%$ & $1981-2010$ \\
MLFYY8110 & mean relative air humidity in the year & $\%$ & $1981-2010$ \\
LFJAN8110 & mean relative air humidity at 1:30 p.m. in January & $\%$ & $1981-2010$ \\
LFAPR8110 & mean relative air humidity at 1:30 p.m. in April & $\%$ & $1981-2010$ \\
LFJUL8110 & mean relative air humidity at 1:30 p.m. in July & $\%$ & $1981-2010$ \\
LFOCT8110 & mean relative air humidity at 1:30 p.m. in October & $\%$ & $1981-2010$ \\
LFYY8110 & mean relative air humidity at 1:30 p.m. in the year & $\%$ & $1981-2010$ \\
\hline
\end{tabular}

\subsection{Solar Radiation}

For elaborating maps of the global radiation, we used the data and followed the procedure of Reference [26]. The maps were recalculated with the resolution of the digital terrain model with a spatial resolution of $25 \mathrm{~m}$. The monthly mean of the global radiation of the months January, April, July and October, as well as the annual mean of the global radiation, were elaborated. The time period was 1984-1993. The ratio between direct radiation and global radiation was estimated according to [26]. The resulting maps are listed and described in Table 5.

Table 5. Resulting maps of solar radiation.

\begin{tabular}{cccc}
\hline Map Abbreviation & Parameter & Unit & Period \\
\hline GLOBRADJAN & average global radiation in January & $\mathrm{Wh} / \mathrm{m}^{2}$ & $1984-1993$ \\
GLOBRADAPR & average global radiation in April & $\mathrm{Wh} / \mathrm{m}^{2}$ & $1984-1993$ \\
GLOBRADJUL & average global radiation in July & $\mathrm{Wh} / \mathrm{m}^{2}$ & $1984-1993$ \\
GLOBRADOCT & average global radiation in October & $\mathrm{Wh} / \mathrm{m}^{2}$ & $1984-1993$ \\
GLOBRADYY & average annual global & $\mathrm{Wh} / \mathrm{m}^{2}$ & $1984-1993$ \\
\hline
\end{tabular}

\subsection{Foehn Conditions}

The foehn wind is of great importance for vegetation, as it has a decisive influence on plants due to its high wind speed, low air humidity and relatively high temperature. In the northern Alpine 
valleys, for example, the foehn prolongs the vegetation period, but also has a very drying effect, so that some hygrophilic plants are severely weakened in their competitive power. In Switzerland, there are essentially two typical foehn phenomena. One is the well-known southern foehn, which is generally called the foehn. This phenomenon usually occurs during southern to south-western currents towards the Alps and affects the areas north of the main Alpine ridge. The second, pronounced foehn phenomenon is the northern foehn, which occurs in the valleys south of the Alpine ridge. The northern foehn can occur in almost any valley. We analyzed the meteorological data in terms of foehn frequency, relative air humidity, and foehn temperature. For this we distinguished foehn conditions from other conditions with the following combination of criteria:

- Relative air humidity: during the day $<=50 \%$, at night $<=55 \%$.

- Wind speed: $>=5 \mathrm{~km} / \mathrm{h}$

- Wind direction range: typical wind direction in ${ }^{\circ}$ with foehn $+/-60^{\circ}$

Each criterion has to be met. The monitoring network in Switzerland has two types of stations that can be used for foehn examinations. Firstly, these are the automatic measuring stations at which certain climate parameters are measured every $10 \mathrm{~min}$. The foehn hours can be counted directly at such stations. However, since there are only a few such stations in the foehn areas, those climate stations had to be taken into consideration which are only observed three times a day, namely in the morning at 7.30 a.m., in the afternoon at 1.30 p.m. and in the evening at 7.30 p.m.. In order to be able to estimate the foehn hours of a day, a simple procedure was used: If a particular station has a foehn condition at a date, the foehn duration of this day was set to $8 \mathrm{~h}$. If a station shows a foehn condition on two dates on a certain day, this results in a foehn duration of $16 \mathrm{~h}$ and if all three dates finally show a foehn condition, the foehn duration of this day is set to $24 \mathrm{~h}$. According to the procedure described above, the number of hours with foehn, the temperature during foehn and the relative air humidity during foehn were evaluated for the year as well as for the months of January, April, July and October. The information obtained at the stations was subsequently used to draw isolines for the number of foehn hours, the temperature and the relative humidity in the southern foehn areas for the year and the months of January, April, July and October at heights of $500 \mathrm{~m}, 1000 \mathrm{~m}$ and $2000 \mathrm{~m}$ a.s.l. The isolines were drawn manually by the experts because usual kriging algorithms do not consider special topographic effects of foehn in valleys. With the help of these isolines, the number of foehn hours, the temperature at foehn and the relative humidity at foehn could be calculated for each grid point, analogously to the procedure for the temperature values at the heights mentioned above. Between the heights 1000 and $2000 \mathrm{~m}$ as well as between the heights 500 and $1000 \mathrm{~m}$ a.s.l. the height gradients of the number of foehn hours, the temperature at foehn and the relative air humidity at foehn were calculated. With the help of the calculated values at $1000 \mathrm{~m}$ and the gradient between 1000 and $2000 \mathrm{~m}$ or the gradient between 500 and $1000 \mathrm{~m}$, the number of foehn hours, the foehn temperature and the relative air humidity could then be determined at each grid point of the digital terrain model at the true altitude at altitudes. The following data were then used for the calculation of the temperature at foehn and the relative humidity at foehn. For grid points with a height of more than $2000 \mathrm{~m}$ a.s.l., we assumed that the frequency of the foehn and the relative humidity during foehn do not change, for the temperature during foehn a uniform height gradient of $-0.7^{\circ} \mathrm{C} / 100 \mathrm{~m}$ increase was assumed. With these assumptions, it was also possible to obtain the foehn parameters above $2000 \mathrm{~m}$ a.s.l. on each grid point. Below $500 \mathrm{~m}$ a.s.l. we assumed that the gradient, which was calculated between the altitudes of $500 \mathrm{~m}$ and $1000 \mathrm{~m}$ a.s.l., was also valid at altitudes below $500 \mathrm{~m}$ a.s.l. With the area-wide data of the number of foehn hours, the temperature during foehn and the relative humidity during foehn at $500 \mathrm{~m}$ and the gradient between $500 \mathrm{~m}$ and $1000 \mathrm{~m}$, the foehn parameters for the grid points, which have a height of less than $500 \mathrm{~m}$, were finally determined. For the areas with northern foehn, the same procedure was applied as for the areas with southern foehn. The foehn duration in hours was subsequently divided by the duration of the period to determine the relative frequency as a share of 
the period. Figure 3 shows the annual frequency of foehn conditions and average relative air humidity during foehn conditions. The resulting maps are listed and described in Table 6.
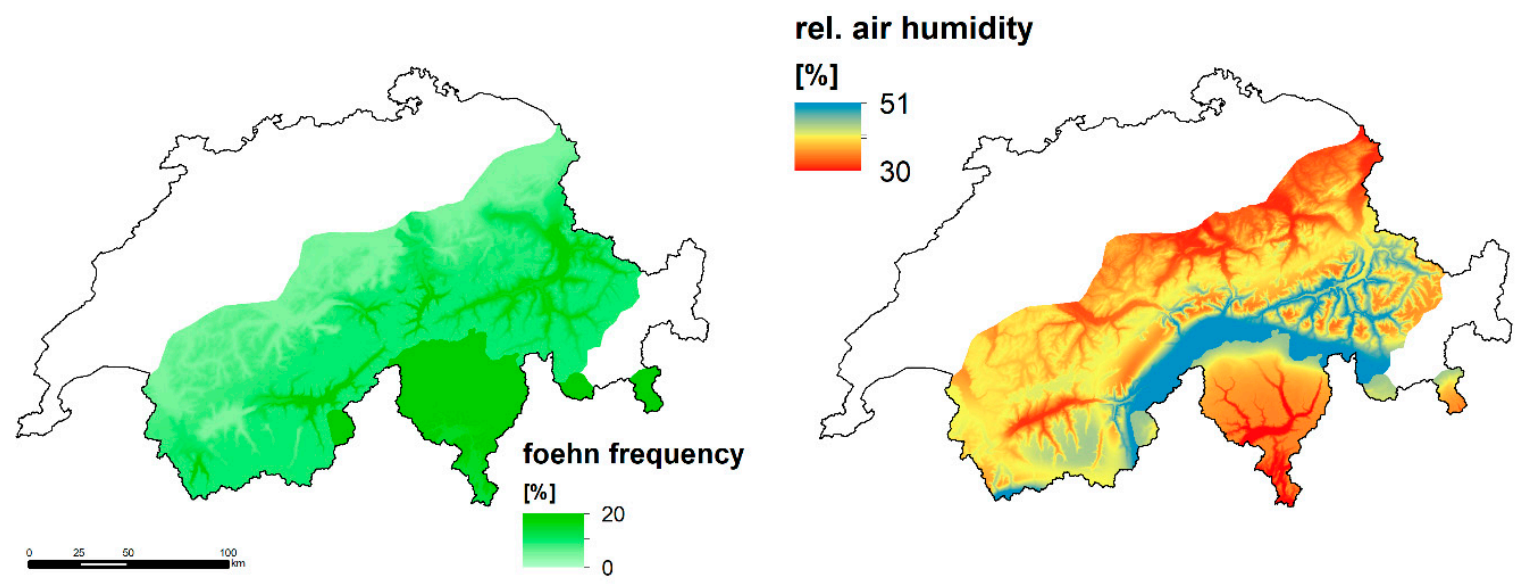

Figure 3. Annual frequency of foehn condition (left) and mean annual relative air humidity during foehn conditions (right) in the period 1981-2010.

Table 6. Resulting maps of foehn conditions.

\begin{tabular}{|c|c|c|c|}
\hline Map Abbreviation & Parameter & Unit & Period \\
\hline FOEHNHJAN & $\begin{array}{l}\text { mean frequency of foehn conditions in January (time with } \\
\text { foehn/time) }\end{array}$ & - & 1981-2010 \\
\hline FOEHNHAPR & $\begin{array}{l}\text { mean frequency of foehn conditions in April (time with } \\
\text { foehn/time) }\end{array}$ & - & 1981-2010 \\
\hline FOEHNHJUL & $\begin{array}{l}\text { mean frequency of foehn conditions in July (time with } \\
\text { foehn/time) }\end{array}$ & - & 1981-2010 \\
\hline FOEHNHOCT & $\begin{array}{l}\text { mean frequency of foehn conditions in October (time with } \\
\text { foehn/time) }\end{array}$ & - & 1981-2010 \\
\hline FOEHNHYY & $\begin{array}{l}\text { mean frequency of foehn conditions in the year (time with } \\
\text { foehn/time) }\end{array}$ & - & 1981-2010 \\
\hline FOEHNTJAN8110 & mean temperature during foehn conditions in January & ${ }^{\circ} \mathrm{C}$ & 1981-2010 \\
\hline FOEHNTAPR8110 & mean temperature during foehn conditions in April & ${ }^{\circ} \mathrm{C}$ & $1981-2010$ \\
\hline FOEHNTJUL8110 & mean temperature during foehn conditions in July & ${ }^{\circ} \mathrm{C}$ & 1981-2010 \\
\hline FOEHNTOCT8110 & mean temperature during foehn conditions in October & ${ }^{\circ} \mathrm{C}$ & 1981-2010 \\
\hline FOEHNTYY8110 & mean temperature during foehn conditions in the year & ${ }^{\circ} \mathrm{C}$ & 1981-2010 \\
\hline FOEHNFJAN & mean relative air humidity during foehn conditions in January & $\%$ & 1981-2010 \\
\hline FOEHNFAPR & mean relative air humidity during foehn conditions in April & $\%$ & 1981-2010 \\
\hline FOEHNFJUL & mean relative air humidity during foehn conditions in July & $\%$ & 1981-2010 \\
\hline FOEHNFOCT & mean relative air humidity during foehn conditions in October & $\%$ & $1981-2010$ \\
\hline FOEHNFYY & mean relative air humidity during foehn conditions in the year & $\%$ & 1981-2010 \\
\hline
\end{tabular}

\section{Discussion and Conclusions}

The presented maps provide a fundamental dataset for the analyses of climate change impacts on mountain forests in Switzerland. The datasets complement other relevant data (e.g., precipitation, wind, geology, duration of heatwaves and droughts) and can be used for statistical analyses of forest climatology or as a baseline for adding the regionalized temperature increase given by climate models. The high-resolution maps can be used to train regression models for the location of treelines and vegetation belts in mountainous areas and tree distribution models aimed at analyzing potential future shifts due to climatic changes. The maps cover the whole of Switzerland. Thus, the presented data allow us to analyze the regional variability of altitude levels of tree lines and vegetation belts. Existing data can be downscaled at the same spatial resolution if needed for extended analyses. This is the case for precipitation data. The maps have been validated by the pool of experts. The interpolation and 
correction methods allowed the consideration of the effects of the micro-relief on temperature. This is on the one side novel; however these corrections base on assumptions and may introduce uncertainties. The interpolation error of the temperature maps is $0.1^{\circ} \mathrm{C}$. The presented datasets can furthermore be used to derive other maps such as for example potential evapotranspiration if combined with wind data. In future analyses, it is to be evaluated if the duration and intensity of heatwaves and droughts are relevant climatological indices. In principle, the data can be used also for other purposes such as for example agriculture. However, since only very rare meteorological stations are located above $2500 \mathrm{~m}$ a.s.l., the presented maps have only limited validity above this altitude.

Author Contributions: Conceptualization, all; methodology and analyses, all; project administration, B.H.; writing, A.Z.

Funding: This research was funded by the Swiss Federal Office for the Environment and the Swiss Federal Institute of Forest, Snow and Landscape Research WSL within the research program "Forests and climate change".

Acknowledgments: We thank the experts involved in the research project for making their expertise explicit. Moreover, we thank MeteoSwiss and SwissTopo for providing their data.

Conflicts of Interest: The authors declare no conflict of interest.

Data Availability: The described data is available at ZENODO, doi:10.5281/zenodo.3245891.

\section{References}

1. Grêt-Regamey, A.; Brunner, S.H.; Kienast, F. Mountain Ecosystem Services: Who Cares? Mt. Res. Dev. 2012, 32, S23-S34. [CrossRef]

2. Klein, J.A.; Tucker, C.M.; Steger, C.E.; Nolin, A.; Reid, R.; Hopping, K.A.; Yeh, E.T.; Pradhan, M.S.; Taber, A.; Molden, D.; et al. An integrated community and ecosystem-based approach to disaster risk reduction in mountain systems. Environ. Sci. Policy 2019, 94, 143-152. [CrossRef]

3. Kulakowski, D.; Bebi, P.; Rixen, C. The interacting effects of land use change, climate change and suppression of natural disturbances on landscape forest structure in the Swiss Alps. Oikos 2011, 120, 216-225. [CrossRef]

4. Moos, C.; Fehlmann, M.; Trappmann, D.; Stoffel, M.; Dorren, L. Integrating the mitigating effect of forests into quantitative rockfall risk analysis-Two case studies in Switzerland. Int. J. Disaster Risk Reduct. 2017, 32, 55-74. [CrossRef]

5. Moos, C.; Toe, D.; Bourrier, F.; Knüsel, S.; Stoffel, M.; Dorren, L. Assessing the effect of invasive tree species on rockfall risk-The case of Ailanthus altissima. Ecol. Eng. 2019, 131, 63-72. [CrossRef]

6. Reyer, C.P.O.; Bathgate, S.; Blennow, K.; Borges, J.G.; Bugmann, H.; Delzon, S.; Faias, S.P.; Garcia-Gonzalo, J.; Gardiner, B.; Gonzalez-Olabarria, J.R.; et al. Are forest disturbances amplifying or canceling out climate change-induced productivity changes in European forests? Environ. Res. Lett. 2017, 12, 034027. [CrossRef] [PubMed]

7. Zischg, A.; Galatioto, N.; Deplazes, S.; Weingartner, R.; Mazzorana, B. Modelling Spatiotemporal Dynamics of Large Wood Recruitment, Transport, and Deposition at the River Reach Scale during Extreme Floods. Water 2018, 10, 1134. [CrossRef]

8. Grêt-Regamey, A.; Bebi, P.; Bishop, I.D.; Schmid, W.A. Linking GIS-based models to value ecosystem services in an Alpine region. J. Environ. Manag. 2008, 89, 197-208. [CrossRef] [PubMed]

9. Kräuchi, N.; Brang, P.; Schönenberger, W. Forests of mountainous regions: Gaps in knowledge and research needs. For. Ecol. Manag. 2000, 132, 73-82. [CrossRef]

10. Lindner, M.; Maroschek, M.; Netherer, S.; Kremer, A.; Barbati, A.; Garcia-Gonzalo, J.; Seidl, R.; Delzon, S.; Corona, P.; Kolström, M.; et al. Climate change impacts, adaptive capacity, and vulnerability of European forest ecosystems. For. Ecol. Manag. 2010, 259, 698-709. [CrossRef]

11. Rutherford, G.N.; Bebi, P.; Edwards, P.J.; Zimmermann, N.E. Assessing land-use statistics to model land cover change in a mountainous landscape in the European Alps. Ecol. Model. 2008, 212, 460-471. [CrossRef]

12. Huber, N.; Bugmann, H.; Lafond, V. Global sensitivity analysis of a dynamic vegetation model: Model sensitivity depends on successional time, climate and competitive interactions. Ecol. Model. 2018, 368, 377-390. [CrossRef] 
13. Seidl, R.; Fernandes, P.M.; Fonseca, T.F.; Gillet, F.; Jönsson, A.M.; Merganičová, K.; Netherer, S.; Arpaci, A.; Bontemps, J.-D.; Bugmann, H.; et al. Modelling natural disturbances in forest ecosystems: A review. Ecol. Model. 2011, 222, 903-924. [CrossRef]

14. Zischg, A. Floodplains and Complex Adaptive Systems-Perspectives on Connecting the Dots in Flood Risk Assessment with Coupled Component Models. Systems 2018, 6, 9. [CrossRef]

15. Grêt-Regamey, A.; Brunner, S.H.; Altwegg, J.; Christen, M.; Bebi, P. Integrating Expert Knowledge into Mapping Ecosystem Services Trade-offs for Sustainable Forest Management. Ecol. Soc. 2013, 18, 34. [CrossRef]

16. Pluess, A.R.; Augustin, S.; Brang, P. Wald im Klimawandel. Grundlagen für Adaptationsstrategien; 1. Auflage; Haupt Verlag: Bern, Switzerland, 2016; ISBN 3258079951.

17. Fabian, Y.; Bollmann, K.; Brang, P.; Heiri, C.; Olschewski, R.; Rigling, A.; Stofer, S.; Holderegger, R. How to close the science-practice gap in nature conservation? Information sources used by practitioners. Biol. Conserv. 2019, 235, 93-101. [CrossRef]

18. Ravetz, J. The post-normal science of precaution. Futures 2004, 36, 347-357. [CrossRef]

19. Huber, B.; Zischg, A.; Burnand, J.; Frehner, M.; Carraro, G. Mit welchen Klimaparametern kann man Grenzen plausibel erklären, die in NaiS (Nachhaltigkeit und Erfolgskontrolle im Schutzwald) verwendet werden um Ökogramme auszuwählen? Schlussbericht des Projektes im Forschungsprogramm "Wald und Klimawandel" des Bundesamtes für Umwelt BAFU, Bern und der Eidg. Forschungsanstalt WSL; ETH Zurich: Birmensdorf, Switzerland, 2015.

20. Gharari, S.; Hrachowitz, M.; Fenicia, F.; Gao, H.; Savenije, H.H.G. Using expert knowledge to increase realism in environmental system models can dramatically reduce the need for calibration. Hydrol. Earth Syst. Sci. 2014, 18, 4839-4859. [CrossRef]

21. Staffler, H.; Pollinger, R.; Zischg, A.; Mani, P. Spatial variability and potential impacts of climate change on flood and debris flow hazard zone mapping and implications for risk management. Nat. Hazards Earth Syst. Sci. 2008, 8, 539-558. [CrossRef]

22. Zischg, A.; Fuchs, S.; Keiler, M.; Meißl, G. Modelling the system behaviour of wet snow avalanches using an expert system approach for risk management on high alpine traffic roads. Nat. Hazards Earth Syst. Sci. 2005, 5, 821-832. [CrossRef]

23. Zischg, A.; Schober, S.; Sereinig, N.; Rauter, M.; Seymann, C.; Goldschmidt, F.; Bäk, R.; Schleicher, E. Monitoring the temporal development of natural hazard risks as a basis indicator for climate change adaptation. Nat. Hazards 2013, 67, 1045-1058. [CrossRef]

24. Zischg, A. High Resolution Maps of Climatological Parameters for Analyzing the Impacts of Climatic Changes on Swiss Forests. Zenodo. 2019. Available online: https://doi.org/10.5281/zenodo.3245891 (accessed on 24 July 2019). [CrossRef]

25. dhm25; swisstopo: Knitz, Switzerland, 2012.

26. Z'Graggen, L. Strahlungsbilanz der Schweiz. Ph.D. Thesis, ETH Zurich, Zurich, Switzerland, 2001.

27. Volken, D. Mesoklimatische Temperaturverteilung im Rhone-und Vispertal. Ph.D. Thesis, ETH Zurich, Zurich, Switzerland, 2008.

(C) 2019 by the authors. Licensee MDPI, Basel, Switzerland. This article is an open access article distributed under the terms and conditions of the Creative Commons Attribution (CC BY) license (http://creativecommons.org/licenses/by/4.0/). 